\title{
System of Rice Intensification: A Review on Resource Conserving Method of Rice Crop Establishment
}

\author{
Hari Kesh*, Khushi Ram and Kuldeep Jangid \\ Department of Genetics and Plant Breeding, CCS Haryana Agricultural University, \\ Hisar-125004, Haryana, India \\ *Corresponding author
}

\section{A B S T R A C T}

Keywords

Economic benefits, Grain yield, SRI, Water use efficiency.

Article Info

Accepted:

17 September 2017

Available Online:

10 November 2017
Rice is commonly grown by transplanting one month-old seedlings into puddled and continuously flooded soil which leads to higher losses of water through puddling, surface evaporation and percolation. Excessive pumping of water for puddling causes problems of declining water table and poor quality water for irrigation. High water need, seed amount, labor costs and labor requirements for TPR have reduced profit margins. During the past years efforts have been tried to find out alternatives to the traditional method of rice cultivation. System of rice intensification a resource conservation method is found to be an efficient alternative to increase the rice production as it require less water, less seed, reducing cost of cultivation and saving labor over time.

\section{Introduction}

Rice is the second largest cereal crop and is the staple food of nearly one half of the world population. Developing countries accounts for 95\% of the total production, with china and India alone responsible for nearly half of the world output. It is grown over $161.4 \mathrm{~m}$. ha. area with production of $749.8 \mathrm{~m}$. t. of paddy and an average productivity of $4.6 \mathrm{t} / \mathrm{ha}$ (Anonymous, 2014). In India, it is cultivated on about approximately $42.75 \mathrm{~m}$. ha. area with production of $154.5 \mathrm{~m}$. $\mathrm{t}$. paddy and productivity of 2.41 t/ha (USDA, 2016).Conventionally, rice is grown by transplanting one month-old seedlings into puddle and continuously flooded soil. The advantages of the conventional / traditional system include increased nutrient availability (e.g. iron, zinc, phosphorus) and weed suppression (Surendra et al., 2001). Puddling, in the conventional transplanting system cause the formation of hard pan below the plough-zone and reduces soil permeability. It leads to water loss through puddling, surface evaporation and percolation. Water resources, both surface and underground, are shrinking and water has become a limiting factor in rice production (Farooq et al., 2009). About $80 \%$ of the available water resources worldwide are used by the agricultural sector (Sujono, 2007). Currently, on-farm 
availability of fresh water is reducing due to many reasons (Uphoff, 2006). Irrigated rice makes the highest water demand. By 2025, it is estimated that 15-20 million hectares of irrigated rice lowlands, which provide three quarters of the world's rice supply, are expected to suffer some degree of water scarcity (IWMI, 2007). It is also estimated that to eliminate hunger and under nourishment for the world's population by 2025 , the additional water requirements may be equivalent to all freshwater withdrawal used today for agriculture, industrial and domestic purposes (SIWI, 2005). In recent years, there has been a shift from conventional transplanted rice to nonconventional production systems. These are resource conserving and economical such as direct seeded rice (DSR) and system of rice intensification (SRI). System of rice intensification emerged as an alternative to enhancing the rice production using less water, seeds, chemical fertilizers and labor.

The system of rice intensification was developed in Madagascar during the 1980s after two decades of observation and experimentation (Laulanie, 1993). Application of SRI principles has helped small farmers in that country to greatly increase their grain yields, from $2 \mathrm{tha}^{-1}$ to $8 \mathrm{t}$ $\mathrm{ha}^{-1}$ and sometimes more (Hirsch 2000; Uphoff and Randriamiharisoa, 2002) on soils that were evaluated as poor or very poor (Johnson 1994).

SRI method is focus on improving the growing environment of rice plants, above and below ground, by improving the management of plants, soil, water and nutrients, to stimulate the growth of bigger and better root systems and the number and activity of beneficial soil organisms (Hidayati et al., 2016). The validity of SRI concepts and methods has been seen now in 42 countries, from Panama to the Democratic People's
Republic of Korea. The governments in China, India, Indonesia, Cambodia, and Vietnam, where two thirds of the world's rice is produced, have come to accept and promote these alternative methods based on their own evaluations and experience (Uphoff et al., 2011). In India, research institutes have initiated experimental trials on SRI across the country in several states including, Tamil Nadu, Andhra Pradesh, Orissa, Tripura, Punjab, Haryana, West Bengal, Chattisgarh, Karnataka, Assam, Bihar, Himachal Pradesh, Uttarakhand, Jammu and Kashmir and Madhya Pradesh to promote among farmers SRI in paddy cultivation (Grihtlahre et al., 2012). The advantages of application of SRI method compared to the conventional method are less seed requirement, water savings up to $50 \%$, reduction in the use of inorganic fertilizers by $50 \%$ if coupled with $50 \%$ organic fertilizer, or some combination of organic fertilizer and biological fertilizer, production costs reduced by $20 \%$, and increasing yield (Hutabarat, 2011). The specific operational practices that derived from Laulanie's work can be stated as follows: i) Transplanting of young seedlings at 8-12 days, when they are at 2-3 leaf stage ii) Transplanting of one seedling per hill with a spacing of $25 \times 25 \mathrm{~cm}$ in a square pattern iii) Apply water during vegetative growth stage at an interval 3 to 6 days.

After panicle initiation, maintain just a thin layer of water, 1-2 cm, until 15 days before harvest iv) manual or mechanical weeding to control the weeds and to aerate the soil v) use of compost as organic matter instead of inorganic fertilizers (Uphoff et al., 2011; Barison and Uphoff, 2011). These practices improve the growth and functioning of rice plants and enhance the numbers and diversity of the soil biota that contribute to plant health and productivity (Stoop et al., 2002; Uphoff, 2003; Randriamiharisoa et al., 2006; Mishra et al., 2006). 


\section{Performance of different rice genotypes under SRI}

Rice hybrids exhibited highest yield potential under SRI method, due to profuse tillering capacity, lodging tolerance, greater stress resistance and wide ecological adaptability (Yan Qingquan, 2002; Rao et al., 2006; Uphoff, 2004; Sowmya, 2008). Rice hybrid 'PHB 71' recorded significantly higher grain yield (12.6\%), harvest index (8.0\%), plant height, leaf area index (LAI), tillers/hill, panicles/hill and grains/panicle during both the years compared to 'NDR 359'(Ram et al., 2014) mainly because hybrid genotypes possess heterosis resulting in vigorous root system, greater source size, higher number of tillers, grains/ panicle and leaf area than the inbred variety (Dey et al., 2006). Singh et al., 2014 evaluated eleven hybrid rice (JRH-4, JRH-5，JRH-8，JRH-10，JRH-11， PRH-10, NPH-207, NPH-567, NPH-4113, NPH-369 and NPH-999) with IR -36 as a control under SRI method of cultivation. Among these hybrids, PRH-10 recorded significantly highest chlorophyll content, dry matter, LAI,CGR, RGR, NAR, root length, root: shoot ratio and grain yield (9.95 t/ha) over the rest of hybrids followed by NPH-567.The lowest values of these parameters were noted in IR-36.Choudhary et al., (2010) tested the field performance of 6 rice hybrids ('KRH 2', 'Arize 6444','PHB 71', 'Indam 100-001', 'PRH 10' and 'Indam 100-003') under system of rice intensification, with inoculation of 3plant growth-promoting rhizobacteria. Higher grain yield was recorded in 'KRH 2' (5.52 tonnes/ha), which is at par to 'Arize 6444' (5.23 tonnes/ha) and 'PHB 71' (4.93 tonnes/ha), but significantly higher than 'Indam 100-003' (4.59 tonnes/ha), 'PRH 10' (4.32 tonnes/ha) and 'Indam 100-001' (3.16 tonnes/ha). Performance of five different rice varieties (Khandagiri, Lalat, Surendra, Hybrid CRHR-7 and Savitri) was compared under System of Rice Intensification (SRI) and current transplanting system (CTS). SRI practices significantly improved the harvest index, percentage of effective tillers, panicle length, and various yield components in all the varieties. Among the varieties, in absolute terms, CRHR-7 and Savitri gave the highest grain yield, under SRI management, while Khandagiri produced the least grain. Similarly, Savitri and CRHR-7 had significantly higher number of tillers and panicles per hill than the others (Thakur et al., (2011).The hybrid PSD-1 performed better in terms of growth and development of the crop, yield components resulting in significantly higher grain yield (4835 kg ha-1) over BPT$5204\left(4453 \mathrm{~kg} \mathrm{ha}^{-1}\right)$. Nutrient uptake was also significantly greater withPSD-1 over BPT5204 (Sowmya, 2008).BRRI dhan29 had a significantly higher grain yield and highest number of effective tillers $/ \mathrm{m}^{2}$ than BRRI dhan28, BRRI dhan35, BRRI dhan36 and BRRI Hybrid dhan 1 under SRI practices (Latif et al., 2005). Ranjitha et al., (2013) reported significantly higher grain yield of hybrid KRH-2 over the other two cultivars i.e., Vasumathi and Krishnahamsa. Veerabhadram, 2013 evaluated four hybrids and eleven varieties for seed yield and quality under system of rice intensification at ICRISAT DRR Farm, Patancheru, Hyderabad. The medium duration rice hybrids (KRH-2, PA6201) gave highest grain yield associated with more number of panicle bearing tillers, high root density, dry matter production and filled grains per panicle. The cultivar HRI-152 gave more seed yield of $66.23 \mathrm{q}$ ha-1 than PR-115 and $17 \mathrm{~A} / \mathrm{R} 10$ which yielded 60.82 and $52.01 \mathrm{q}$ ha1 respectivelyunder SRI method of rice cultivation (Mahajan and Sarao, 2009).Singh et al., (2015) reported that long duration variety Swarna produced more grain and straw yield than followed by BPT 5204, IR 64 and Lalat. For yield attributes Swarna was significantly superior to IR-64 and Lalat but remained at par with BPT-5204 as Swarna 
andBPT-5204 being long duration varieties gets more time to complete the life cycle in comparison to medium duration varieties i.e. IR-64 and Lalat. Rice cultivar 'PHB 71'exhibited significantly higher grain yield, straw yield and harvest index, plant height, tillers/hill, LAI, dry-matter accumulation with delayed flowering and physiological maturity and effective tillers/m2, grains/panicle and test weight over 'Pusa RH-10 (Vishwakarma et al., 2016).

\section{Growth traits under SRI system of rice cultivation}

In SRI planting strategy, there was less trauma to the root system and the plants recover from the shock of transplanting more quickly which preserve the potential of the plant for much greater tillering, faster root growth and grain filling (Uphoff, 2002).Transplanting of younger seedlings increased drymatter production in SRI method as compared to the normal system of cultivation (Uphoff, 2001). Gani et al., (2002) recorded more vigorous vegetative plant growth of seedlings of 7 to $14 \mathrm{~d}$ age than 21 d-old seedlings. They produced more effective tillers, biomass, taller plants, and longer roots. Younger seedlings had a longer time to adapt to field condition, therefore the plant height and tiller number produced were higher in the SRI method. In addition, single seedling is planted per hill with a wide spacing in SRI method. It reduces the competition between the plants for nutrients uptake, water, light and air which can significantly increase the growth of individual rice plant under the SRI method (Thakur et al., 2010). In SRI method the leaf area index (LAI) was higher i.e., 1.82 at tillering, 3.65 at panicle initiation, and 4.44 at flowering over the standard method with 4.40, 4.78, and 4.16 in the respective stages (Lokanadhan et al., 2007). Sridevi and Chellamuthu (2015) reported that transplanting of 14 days old seedlings at a spacing of $22.5 \mathrm{~cm} \mathrm{x} 22.5 \mathrm{~cm}$ and cono weeding four times at weekly interval had profound contribution for the enhancement of growth parameters like leaf area index, crop growth rate, net assimilation rates, relative growth rate, leaf area ratio and dry matter. The leaf number of rice increases with increasing number of tillers. Likewise, the leaf area increased due to a greater leaf elongation rate which may contribute to making the leaves wider (Thakur et al., 2011). Reddy (2004) observed that BPT-5204 variety flowered 4-5 days earlier under SRI system of cultivation as compared to the traditional method of planting. Singh et al., (2004) reported that 11 days difference in 50 per cent flowering between 21 and 51 days old seedlings in Pusa Basmati-1. Udaykumar (2005) reported that days to 50 per cent flowering and maturity was 4-5 days early (71 and 116) as compared normal method (75 and 120 days) in MTU- 1010 rice variety.

Root growth was markedly greater in SRI plants than in traditional rice plants. The total dry matter production was higher in SRI method of planting than traditional rice, this difference becoming significant during the reproductive stage (Longxing et al., 2002). Maintaining the soil in moist but not flooded conditions provided good aeration for the plant roots. These favorable conditions for growth with SRI methods allowed to complete more phyllochrons of growth, producing more tillers and roots, before the flowering phase (Hidayati et al., 2016). Rupela et al., (2006) reported that rice plants in the SRI plots had about 10 times more root mass, about 5 times more root length density and about 7 times more root volume in the top $30 \mathrm{~cm}$ of soil profile as compared with roots in the plots of flooded rice. Satyanarayana et al., (2007) confirmed that the SRI plants have deeper root systems and larger roots compared to those conventionally grown in flooded rice systems. Root growth and root 
exudation rate hill ${ }^{-1}$ were significantly higher in SRI plant (Thakur et al., 2006)

Yield and its components under SRI system of rice cultivation

SRI is a methodology for increasing the productivity if irrigated rice cultivation by changing the management of plants, soil, water and nutrients by reducing external inputs. It has been raising yields by $32 \%$ to $100 \%$ and sometimes more, with reduced requirements for water, seed, fertilizer and crop protection (Sato and Uphoff, 2007; Sinha and Talati, 2007). Omwenga et al., (2014) monitored yield parameters like number of tillers, panicles, panicle length and panicle filling during the growth period of the crop to determine the effect of system of rice intensification. Eight days drying period gave the highest yield of 7.13 tons/ha compared with the conventional method of growing rice which gave a yield of 4.87 tons/ha. This was an increase of $46.4 \%$ above the conventional method of growing rice. Higher yield attributes like number of productive tillers $\mathrm{m}^{-2}$, length of panicle and numbers of grains panicle $^{-1}$ showed the higher grain yield of $6082 \mathrm{~kg} \mathrm{ha}^{-1}$ which was significantly higher than conventional method of rice cultivation $\left(5223 \mathrm{~kg} \mathrm{ha}^{-1}\right)$ under SRI system (Ponni et al., 2010). The combination of 10 days aged seedlings, $100 \%$ nutrients through inorganic sources $\left(\mathrm{A}_{10} \mathrm{~F}_{100} \mathrm{WmIs}\right)$ or $50 \%$ through inorganic $+50 \%$ through organic sources $\left(\mathrm{A}_{10} \mathrm{M}_{50} \mathrm{~F}_{50} \mathrm{WmIs}\right)$, weeds controlled thrice mechanically by cono weeder and irrigation as per SRI i.e., $2 \mathrm{~cm}$ at hairline crack development stage gave similar and maximum yield attributes and yield of hybrid rice. This combination $\left(\mathrm{A}_{10} \mathrm{~F}_{100} \mathrm{WmIs}\right)$ produced higher grain yield $\left(7.52 \mathrm{t} \mathrm{ha}^{-1}\right)$ than recommended practices of hybrid rice $(6.50 \mathrm{t}$ $\mathrm{ha}^{-1}$ ) with the increase in grain yield was $13.52 \%$ (Verma et al., 2014). Raju et al., (1989) observed more filled grains per panicle and grain yield per plant under SRI method of cultivation. Significantly higher seed yield ha ${ }^{1}$ was noticed with a spacing of $30 \times 30 \mathrm{~cm}$ and transplanting 12 days old seedlings (Krishna et al., 2008) under SRI system of cultivation. Babu (2007) recorded higher grain yield in SRI as compared to conventional method. Makarim et al., (2002) found that 15 day old seedlings gave significantly higher grain yields than 21-d-old seedlings when a single seedling was planted hill $^{-1}$. SRI registered a mean grain yield of $5505 \mathrm{~kg} \mathrm{ha}^{-1}$ which was significantly higher than conventional method of rice cultivation $\left(4510 \mathrm{~kg} \mathrm{ha}^{-1}\right)$. Thus significant superiority of SRI in terms of grain yield was evident due to 22.1 per cent yield increment by SRI. Higher yield attributes like number of productive tillers $\mathrm{m}^{-2}$, length of panicle and numbers of grains panicle ${ }^{-1}$ under SRI attributed the higher grain yield of SRI (Pandiselvi et al., 2010). Bommaiasamy (2005) reported that transplanting of 14 days old seedlings at $20 \mathrm{x}$ $20 \mathrm{~cm}$ spacing results in $7.2 \%$ higher yield than 21 days old seedlings under SRI system. Udaykumar (2005) confirmed that SRI recorded significantly higher seed yield of $6136 \mathrm{~kg}$ ha-1 compared to traditional method of cultivation $\left(4282 \mathrm{~kg} \mathrm{ha}^{-1}\right)$ in MTU -1010 rice variety. The yield attributing parameters viz., number of productive tillers, number of filled spikelets and panicle length were also high with this method.

\section{Water saving under SRI system of rice cultivation}

The most important feature of SRI Technique was its potentiality to save water. SRI is reported to reduce amount of water applied to the field by about $40-70 \%$ compared to the traditional practice of continuous flooding (Sato and Uphoff, 2007; Sinha and Talati, 2007).On an average, $406 \mathrm{~mm}$ water was saved under SRI(Mevada et al., 2016), which tuned to $33.47 \%$ saving over farmer's 
practice (FP). So, for production of $1 \mathrm{~kg}$ grains of rice, 2426 liter of water was sufficient under SRI, as against 3743 lit. water required for producing the same quantity under FP, indicating about $35 \%$ higher efficiency of water under SRI over FP. Likewise, WUE was also higher $(4.12 \mathrm{~kg} / \mathrm{ha}-$ $\mathrm{mm}$ ) under SRI as compared to FP (2.67 $\mathrm{kg} / \mathrm{ha}-\mathrm{mm}$ ). Zhao et al., (2010) reported that the total water consumption in SRI was 898.3 $\mathrm{mm}$ as compared to traditional flooding (TF) in which it was $1359.8 \mathrm{~mm}$. The irrigation water use was reduced by $57.2 \%$ in SRI compared to TF. Water use efficiency (WUE) in terms of grain yield per unit consumed by water increased $91.3 \%$ for SRI. Irrigation water use efficiency (IWUE) in terms of grain yield per unit irrigation water improved by $194.9 \%$ for SRI compared to TF. Thus, SRI treatment reduced water consumption and increased WUE and IWUE significantly as compared to TF. Higher grain yield coupled with substantial water saving i.e. 35 per cent (Pandiselvi et al., 2010) and 24. 1 Per cent (Pooni et al., 2010) resulted in higher WUE of rice under SRI method. SRI method of transplanting resulted in significantly higher total water productivity $(5.9 \mathrm{~kg} / \mathrm{ha}-\mathrm{mm})$ in upland ecology and (6.2 kg/ha-mm) in lowland ecology as compared to other two methods viz. direct-seeded rice and puddled transplanted rice (Raj et al., 2017).

\section{Physiological traits under SRI system of rice cultivations}

SRI methods significantly increased both vegetative and reproductive parameters of rice plants compared to conventional cultivation methods. Photosynthetic rate, chlorophyll content, $\mathrm{N}$ and $\mathrm{P}$ uptake under SRI cultivation were found significantly higher as compared to the conventional rice cultivation, but no differences were observed in transpiration rate and leaf temperature. Plants in their generative phase especially in the grain-filling phase had the highest photosynthetic and the lowest transpiration rates under SRI system of planting (Hidayati et al., 2016). Due to wider spacing between hills, rice plants showed wider canopy under SRI system than those in conventional method. The wide canopy increases the penetration of light to reach to lower leaves, thus maximizing opportunity for all of the leaves to perform photosynthesis optimally (Terashima and Hikosaka, 1995).Chlorophyll content of fourth leaves from the flag leaf was found to be significantly higher in SRI plants (by 27$73 \%$ ) compared to current transplanting system (CTS) plants in all the varieties during early ripening or milk grain stage. Similarly, the rate of photosynthesis was also higher for the fourth leaves from the flag leaf at the early ripening stage of SRI plants compared to CTS. Leaves from SRI plants showed photosynthesis rates $48-69 \%$ higher than in CTS leaves. The hybrid and long-duration variety maintained significantly higher rates of photosynthesis than did the short-duration variety under both SRI and CTS (Thakur et al., 2011). Previous reports suggests that a well-developed root system enhances the synthesis of cytokinins in roots (Soejima et al., 1995; San-oh et al., 2004), and the rate of leaf senescence is lower in plants that have larger amounts of cytokinins transported into their canopies from the roots (Soejima et al., 1995). Increased transport of cytokinins to above-ground parts of the plant from the roots during ripening is associated with the maintenance of increased rates of photosynthesis in rice (Ookawa et al., 2004; Soejima et al., 1992, 1995). Plants from pattern I (one plant per hill)maintained higher rates of leaf photosynthesis at the middle and late ripening stage due to the maintenance of higher levels of leaf nitrogen and Rubisco than plants from pattern III (three plant per hill). Pattern I plants, which produced a larger number of crown and branched roots, accumulated a larger amount of nitrogen and 
transported a larger amount of cytokinins from roots to shoot in the ripening stage than pattern III plants (Shan-oh et al., 2006).The highly efficient photosynthetic performance of super high-yielding rice is largely a result of the increased cytokinin content in their roots, contributing to higher grain yield (ShuQing et al., 2004).

\section{Seed quality traits under SRI system of rice cultivation}

The SRI method of cultivation considerably increases the seed yield and seed quality in traditional rice varieties when grown organically (Fernandes and Uphoff, 2002). Udaykumar (2005) reported that better seed quality parameters under SRI method like higher germination per cent (95.56), root length $(5.44 \mathrm{~cm})$ and shoot length $(5.49 \mathrm{~cm})$ higher values of speed germination (31.11) and vigour index (991) compared to that under normal method. Kanaka Durga et al., (2015) reported that the twelve days old seedlings planted at $25 \times 25 \mathrm{~cm}$ recorded $100 \%$ germination, with longer seedlings and seedling high vigour index I. Seed produced with SRI under spacing of $25 \mathrm{~cm} \mathrm{x} 25 \mathrm{~cm}$ recorded higher germination $(98.60 \%)$ as compared to conventional $(95.0 \%)$ with close spacing of $20 \times 15 \mathrm{~cm}$. The vigour index was significantly higher with SRI. The better seed quality produced under SRI may be due to higher test weight values (Singh et al., 2013). Seed quality parameters viz., seedling length (root length and shoot length, separately), seedling dry weight and vigour index recorded significantly higher values in SRI method (Kumar, 2014).

\section{Grain quality traits under SRI system of rice cultivation}

SRI was found better over traditional method in respect of grain quality of rice. Hulling, milling and head rice recovery in rice improved significantly under SRI over conventional method and this might be attributed to the improvement of root activity, dry matter accumulation and grain filling (Mandal et al., 2014). Milling percentage and head rice recovery were significantly higher (4.4\% and $4.8 \%$ during wet and dry season respectively) under SRI as compared to nonSRI (Satyanarayana et al., 2004) due to higher grain weight. Grain quality parameters such as the grain length $(7.77 \mathrm{~mm})$, amylose content $(25.83 \%)$, alkali spreading value, Fe (2.06 ppm) and $\mathrm{Zn} \mathrm{(13.23} \mathrm{ppm)} \mathrm{content}$ (polished rice) recorded significantly higher values in SRI method compared to grain length $(7.47 \mathrm{~mm})$, amylose content $(25.09 \%)$, alkali spreading value, Fe (1.77 ppm) and $\mathrm{Zn}$ (12.07 ppm) content (polished rice) under conventional transplanting (CT) (Kumar, 2014).

\section{Incidence of insect pests and diseases under SRI system of rice cultivation}

Rice crop is damaged by a large number of insect pests, natural enemies and disease that cause an overall estimated yield loss of 2151\%(Arya and Chander 2012).Very few reports are available on the insect pests, natural enemies and disease scenario in SRI system (Karthikeyan et al., 2007), some of which are reviewed here. Low pest incidence in rice grown under SRI due to vigorous and healthy growth of plant coupled with wider spacing had been reported by Ravi et al., (2007). Two rice varieties viz. Deku (local variety) and CAU R-1(improved variety) were investigate and compare the occurrence of insect-pests, natural enemies and diseases in SRI and traditional system of rice cultivation under north-east region conditions of India. The pooled results of two cropping seasons revealed that prevalence of stem borer, blue beetle, case worm, leaf folder and gundhi bug $/ \mathrm{m}^{2}$ were lower in both the varieties under SRI system as compared to 
traditional system. Among diseases the incidence of blast, sheath blight, brown spot, false smut, bacterial leaf stripes and bacterial blight was found to be lower in SRI in both the varieties as compared to a higher level of incidence under traditional systems (Pathak et al., 2012). Karthikeyan et al., (2010) reported that the incidence of stem borer was significantly lower in SRI $(4.82 \%$ in Jyothi and $2.35 \%$ in CORH 2) during the vegetative phase compared to standard method of cultivation $(9.75 \%$ in Jyothia and $9.85 \%$ in CORH 2), while at the reproductive phase there was no significant difference between the two systems of cultivation. The incidences of whorl maggot and caseworm were lower under SRI system but the incidence of leaf folder was higher in the crop under SRI than the standard system. Padmavathi et al., 2009 observed that yellow stem borer damage was high at all stages of crop growth period and its damage (dead hearts) at maximum tillering stage was low in cv. Shanti grown under SRI (7.0\%) as compared to conventional method $(11.4 \%)$. At reproductive stage, the damage (white ear heads) was high in SRI (28.3\%) than conventional method (21.2\%). Ravi et al., (2007) reported low white ear heads damage in BPT 5204, ASD 19, Swarna and ADT 46 under SRI method due to vigorous and healthy growth of plant coupled with wider spacing. Shengfu et al., (2002) recorded that incidence of rice sheath blight was less when planted at $33.3 \mathrm{cmx} 33.3 \mathrm{~cm}(58.4 \%)$ spacing or $40 \mathrm{~cm} \times 40 \mathrm{~cm}(54.6 \%)$ spacing under SRI than that with traditional cultivation $(70 \%)$.

Economic benefits from system of rice intensification

Ponni et al., (2010) compared the rice cultivation under system of rice intensification (SRI) and conventional method. The study revealed that the cost of cultivation was comparatively lesser in SRI than conventional method. The mean cost of cultivation for SRI and conventional method was Rs. 20,944 $\mathrm{ha}^{-1}$ and Rs. 23,111harespectively. Thus it is evident that adoption of SRI was found to reduce the cost of cultivation by Rs.2167ha-1.SRI registered a total income of Rs.61, $000 \mathrm{ha}^{-1}$ and net profit of Rs.40, $056 \mathrm{ha}^{-1}$ as compared to Rs.52, 167 $\mathrm{ha}^{-1}$ and Rs. 29,056 $\mathrm{ha}^{-1}$, respectively under conventional method. Higher $\mathrm{BC}$ ratio was also associated with SRI (2.91) than conventional method (2.26). Ram et al., (2014) concluded that use of 10 days old seedlings of hybrid rice 'PHB 71' at spacing of $25 \mathrm{~cm} \times 25 \mathrm{~cm}$ is most suitable to increase productivity and profitability of transplanted rice under Eastern Utter Pradesh conditions. Nayak et al., (2016) evaluated economic advantages of SRI practices of paddy transplanting as compared to conventional method in Odisha. The yield differences showed that farmers growing paddy by SRI method could get a 6.6 q more paddy as compared to traditional method of transplanting. Benefit: cost ratio indicates that SRI method was more effective as if we invest one rupee the total return would be 2.18 whereas in case of traditional method this figure would be 1.45 . Thus it can be concluded that with less inputs farmers can earn more.SRI could fetch 16.8 and 23.7\%higher gross return, 36.7 and $51.7 \%$ higher net return and 16.3 and $21.3 \%$ higher return $\mathrm{re}^{-1}$ invested than conventional transplanting and drum seeding, respectively as per mean yield. This was mainly because of higher yields obtained in SRI as compared to the other two methods during both the years (Mohanty, et al., 2014).The net returns and benefit-cost ratios were higher for SRI farms due to higher productivity of paddy cultivation (Durga and Kumar, 2013).

SRI is a new technology of rice crop establishment that enhance the productivity of the crop with minimum use of resources such 
as seeds, water, capital and labor. The practices of SRI such as single seedling per hill and wider spacing helps the rice plants to better utilize the water and nutrients thereby increase the water and nutrient use efficiency. Yield of different varieties was significantly higher in SRI as compared to traditional transplanting. Within SRI, the different varieties performed differentially. So, there is need to develop varieties that respond better under SRI practices.

\section{References}

Anonymous, 2014. www.fao.org. Food and Agriculture Organization, Rome, Italy.

Arya, K. and Chander, S. 2012. Formulation of detection support tools for management of rice leaf folder. Ann. Pl. Protec. Sci., 20: 134-139.

Babu, M.K. 2007. Performance of SRI over conventional method under Bore well irrigation system and perception of farmers in Nalganda District of A.P. 2nd National Symposium on SRI $3^{\text {rd }}$ $5^{\text {th }}$ October 2007 Agartala, Tripura India pp. 162-165.

Barison, J. and Uphoff, N. 2011. Rice yield and its relation to root growth and nutrient-use efficiency under SRI and conventional cultivation: an evaluation in Madagascar. Paddy and Water Environ., 9: 65-78.

Bommaiasamy, P. 2005. Optimization of establishment techniques for SRI. MSc. (Agri) Thesis, TNAU, Coimbatore.

Choudhary, R.L., Kumar, D., Shivay, Y.S., Lata, Singh, G.and Singh, N. 2010. Performance of rice (Oryza sativa) hybrids grown by the system of rice intensification with plant growthpromoting rhizobacteria. Indian J. Agric. Sci., 80 (10): 917-20.

Dey, R.C., Haloi, B., Ghose, T.J. and Chetia, S.K. 2006. Productivity of rice hybrids and high yielding varieties under rainfed shallow (favourable) ecology. Oryza, 43(1): 51-54.

Durga, A. R. and Kumar, D.S. 2013. Economic analysis of the system of rice intensification: Evidence from Southern Indua. Bangladesh Development Studies, 36:79-93.

Durga, K.K., Rao, P.S. and Raju, K. 2015. Effect of seedling age and spacing schedule on the productivity and quality traits of rice under system of rice intensification (SRI). J. cereals oilseeds, 6:15-19.

Farooq, M., Wahid, A., Lee, D.-J., and Siddique, K.H.M. 2009. Advances in drought resistance of rice. CRC Crit. Rev. Plant Sci., 28:199-217.

Fernandes, E.C.M. and Uphoff, N. 2002. Summary from conference reports. In :Assessment of the System of Rice Intensification (SRI) : Proceedings of an International Conference, Sanya, China, April 1-4, 2002, pp. 33-39.

Gani, A., Rahman, A., Dahono, Rustam and Hengsdijk, H. 2002. Synopsis of watermanagement experiments in Indonesia. In: Water Wise Rice Production, IRRI, pp.29-37.

Ghritlahre, S.K., Sarial, A.K., Ram, M.R., Aneja, D.R. and Singh, R. 2012. Genetic yield potential of rice (Oryza sativa L.) through water saving and high yielding SRI technology. Indian J. Agric. Sci., 82 (3): 260-263.

Hidayati, N., Triadiati and Anas, I. 2016. Photosynthesis and transpiration rates of rice cultivated under the system of rice intensification and the effects on growth and yield. HAYATI J. Biosci., 23:67-72.

Hirsch, R. 2000. La Riziculture Malgache Revisite'e: Diagnostic etPerspectives (1993-99). Agence Franc, aise de De'veloppement,Antananarivo, Annexes, pp. 13-14.

Hutabarat, T.R. 2011. Populasi mikrob tanah emisi metan dan produksi padi dengankombinasi pemupukan pada budidaya padi SRI (System of Rice Intensification)[Thesis]. Bogor: Bogor Agricultural Univ.

IWMI, 2007. International Water Management Institute. Rice: Feeding the Billions, 
Chapter14: Water for food, Water innovations: Stockholm, Sweden.

Johnson, B.K. 1994. Soil survey. In: Final report for the agricultural development component of the Ranomafana National Park Project in Madagascar. Soil Science Dept, North Carolina State University, Raleigh, NC, pp 5-12.

Karthikeyan, K., Jacob, S. and Purushothaman, S.M. 2010.Incidence of insect pests and natural enemies under SRI method of rice cultivation. Oryza, 47(2):154-157.

Karthikeyan, K., Revi, S., Balachandran, P.V., Shanmugasundaram, B. and, Purushothaman, S.M. 2007. Influence of SRI Cultivation on the Incidence of major pests of Rice. In: Gujja B, Goud VV, Mahendrakumar R, Rao PP, Prasad CS and Shib S. (Eds.) Second National Symposium on System ofRice Intensification (SRI) in India- Progress and Prospects, 3-5 Oct., 2007 Agartala, India. pp 96-97.

Krupakar Reddy, G. 2004. Varietal performance and spatial requirement of rice under System of Rice Intensification during Kharif season.M.Sc. (Agri) Thesis, Acharya N.G. Ranga Agricultural University, Hyderabad.

Kumar, G. 2014. Evaluation of system of rice intensification (SRI) for enhanced seed yield and quality. M.Sc. (Ag.) Thesis. Acharya N G Ranga Agricultural University, Hyderabad, India.

Latif, M.A., Islam, M.R., Ali, M.Y. and Saleque, M.A.2005. Validation of the system of rice intensification (SRI) in Bangladesh. Field Crops Res., 93 (2/3): 281- 292.

Laulanie, H. 1993. Le systeme de rigiculture intensive malagache. Tropicultura (Brussels)11: 104-114.

Lokanadhan, S., Ravichandran, V., Suresh, S., Rabindran, R., Thiyagarajan, $\mathrm{K}$ and Mohanasundaram, K. 2007. Efficient resource utilization in SRI method of Rice(CORH3) cultivation - An analysis. In SRI India 2007 Second National Symposiumon 'System of Rice
Intensification (SRI) in India - Progress and Prospects'. Papers and Extended Summaries, 3-5 October 2007, Agartala, Tripura, India. 79-81.

Mahajan, G. and Sarao, P.S. 2009. Evaluation of system of rice (Oryza sativa L.) intensification (SRI) in irrigated agroecosystem of Punjab. J. Res. ANGRAU, $37: 1-6$.

Makarim, A.K., Balasubramanian, V., Zaini, Z., Syamsiah, I.,Diratmadja, I.G.P.A., Handoko, A., Wardana, I.P. and Gani,A. 2002. Systems of rice intensification (SRI): Evaluation of seedling age and selected components in Indonesia. In: Water-Wise Rice Production, pp 129-39 (Eds. B.A.M. Bouman, A. Hengsdijk, B. Hardy, P.S. Bindraban, T.P. Tuong and J.K. Ladha). Los Baños, Philippines: IRRI.

Mandal, M.K., Pramanick, M. and Bandopadhyay, P. 2014. Influence of crop establishment systems on yield and qualityof rice grain and seeds of aromatic rice (Oryza sativa L.). Green Farming, 5(6): 951-955.

Mevada, K.D., Patel, M.V. and Chauhan, N.P. 2016. Performance of system of rice intensification (SRI) technique in rice (Oryza sativa L.) on farmer's field. Guj. J. Ext. Edu., 27(1): 13-17.

Mishra, A., Whitten, M., Ketelaar, J.W. and Salokhe, V.M. 2006. The System of Rice Intensification (SRI): A challenge for science, and an opportunity for farmer empowerment towards sustainable agriculture. Int. J. Agri. Sustain., 4: 193212.

Mohanty, T.R., Maity, S.K. and Roul, P.K. 2014. Response of rice to establishment methods and nutrient management practicesin medium land. Oryza, 51(2): $36-42$.

Mohanty, T.R., Maity, S.K., Roul, P.K. and Sahoo, K.C. 2014.Studies on yield, economics and energetics of rice (Oryza sativa L.) in relation to crop establishment methods and nutrient management practices. Int. J. Bio-res. 
Stress Manage., 5(4):495-501.

Nayak, C., Mahunta, R. and Dash, S. 2016. Economic Benefits of system of rice intensification (Sri) in Kendrapara district of Odisha. Int. J. Appl. Pure Sci. Agric., 2:220-225.

Omwenga, K.G., Mati, B.M., and Home, P.G. 2014. Determination of the Effect of the System of Rice Intensification (SRI) on Rice Yields and Water Saving in Mwea Irrigation Scheme. Kenya. J. Water Resource Prot., 6:895-901.

Ookawa, T., Naruoka, Y., Sayama, A., Hirasawa, T. 2004. Cytokinin effects on ribulose-1,5-bisphosphate carboxylase/ oxygenase and nitrogen partitioning in rice during ripening. Crop Sci., 44:21072115.

Padmavathi, C., Kumar, R.M., Subba Rao, L.V., Surekha, K., Prasad. M. S., Babu, V. R. and Pasalu, I.C. 2009. Influence of SRI method of rice cultivation on insect pest incidence and arthropod diversity. Oryza, 46:227-230.

Pandiselvi, T., Veeraputhiran,R., Ganesaraja,V., Ponni Priya, J. and Pandian, B.J. 2010. Productivity, water use efficiency and economics of system of rice intensification in Sivagangai district of Tamil Nadu. Int. J. Agric. Sci., 6 (1): 138140.

Pathak, M., Shakywar, R.C. and Sah, D. and Singh, S. 2012. Prevalence of insect pests, natural enemies and diseases in SRI (System of Rice Intensification) of Rice cultivation in North East Region. Ann. Pl. Protec. Sci., 20 (2): 375-379.

Ponni Priya, J. Veeraputhiran,R.,Ganesaraja,V., Pandiselvi, T., and Pandian, B.J. 2010. Comparative study of system of rice intensification and conventional method of rice cultivation in Madurai district of Tamil Nadu. Int. J. Agric. Sci., 6(1): 186188.

Raghuveer Rao, P., Mahender Kumar, R., Ram Prasad, A.S and Ravichandran, S. 2006. System of Rice Intensification (SRI) versus traditional method of rice cultivation (TRC). In: National
Symposium on System of Rice Intensification (SRI) - Present Status and Future Prospects, November 17-18, 79.

Raj, R., Kumar, A., Solanki, I. S., Dhar, S. Dass, A., Gupta, A.K., Kumar, V., Singh, C. B., Jat, R. K. and Pandey, U. C. 2017. Influence of crop establishment methods on yield, economicsand water productivity of rice cultivars under upland and low land production ecologies of Eastern Indo-Gangetic Plains. Paddy Water Environ., 15:861-877.

Raju, R.A., Reddy, G.V and Reddy, M.N.1989. Response of long duration rice to spacing and age of seedlings. Indian J. Agro., 34 (4): 506-507.

Ram, H., Singh, J.P., Singh, R.K., Bora, J.S. and Sutaliya, J.M.2014. Effect of seedling age and plant spacing on growth, yield, nutrient uptake and economics of rice genotypes under system of rice intensification. Indian J. Agro., 59(2): 256-60.

Randriamiharisoa, R., Barison, J. and Uphoff, N. 2006. Soil biological contributions to the System of Rice Intensification. In: Uphoff Net al., (eds) Biological strategies for sustainable soil systems. CRC Press, Boca Raton, FL, pp 409-424.

Ranjitha, P.S.,Kumar, R.M., and Jayasree, G. 2013. Evaluation of rice (Oryza sativa L.) varieties and hybrids in relation to different nutrient management practices for yield, nutrient uptake and economics in SRI. Ann. Biol. Res., 4(10):25-28.

Ravi, G., Rajendran, R., Raju N, Chozhan K and Muralidharan, V. 2007. Insect pest Scenario in Irrigated Rice under SRI method of Cultivation. In: Gujja B, Goud VV., Mahendra Kumar R, Rao PP, Prasad CS and Shib S(Eds.) Second National Symposium on System of Rice Intensification (SRI) in India- Progress and Prospects, 3-5 Oct.,2007, Agartala, India. pp 94-95.

Rupela, O.P., Wani, S.P., Kranthi, M., Humayun, P., Satyanarayana, A., Goud, V., Gujja, B., Punnarao, P., Shashibhushan, V., Raju, D.J. and 
Reddy, P.L. 2006. Comparing soil properties of farmers' fields growing rice by SRI and conventional methods. In: Proceedings of 1st National SRI Symposium, 17-18 November. World Wide Fund for Nature-ICRISAT Dialogue Project, Patancheru, Hyderabad San-oh, Y., Mano, Y., Ookawa, T., Hirasawa, T. 2004. Comparison of drymatter production and associated characteristics between directs own and transplanted rice plants in a submerged paddy field and relationships to planting patterns. Field Crops Res., 87:43-58.

San-oh, Y., Sugiyama, T., Yoshita, D., Ookawa, T., Hirasawa, T. 2006. The effect of planting pattern on the rate of photosynthesis and related processes during ripening in rice plants. Field Crops Res., 96: 113-124.

Sato, S. and Uphoff, N. 2007. A review of onfarm evaluations of system of rice intensification (SRI) method in eastern Indonesia. In: Perspectives in Agriculture, Veterinary Science, Nutrition and Natural Resources. Commonwealth Agricultural Bureau International, Wallingford, UK.

Satyanarayana, A., Thiyagarajan, T.M., Uphoff, N. 2007. Opportunitiesfor water-saving with higher yield from the system of rice intensification. Irrig. Sci., 25:87-97.

Satyanarayana, P. V., Srinivas, T. and Satyanaraya, A. 2004. In Proc. World Rice Research Conference, Tsukuba International Congress center, Tsukuba, Japan. 4-7 Nov. 2004.

Shao-hua, W., Weixing, C., Dong, J., Tingbo, D. and Yan, Z. 2002. Physiological characteristics and high yield techniques with SRI rice. pp. 116-125. In Proc. Intl. Conf. Assessments of the System of Rice Intensification (SRI), Sanya, China. 1-4 Apr. 2002.

Shengfu, A., Xiehui, W., Zhongjiong, X. and Shixiu, X. 2002. Assessment of using SRI with the super hybrid rice variety Liangyoupei 9. p. 112-115. In Proc. Intl. Conf. Assessments of the System of Rice Intensification (SRI), Sanya, China. 1-4
Apr. 2002.

Shu-Qing, C., Rong-Xian, Z., Wei, L., Zhi-Rui, D. and Qi-Ming, Z. 2004. The involvement of cytokinin and abscisic acid levels in roots in the regulation of photosynthesis function in flag leaves during grain filling in super high yielding rice (Oryza sativa). J. Agron. Crop Sci., 190, 73-80.

Singh, C. S., Singh, M., Singh, S. K., Singh, A. K. and Singh, A.K. 2015. Growth and yield response of rice cultivars under system of rice intensification and conventional method of rice production system. The Ecoscan, 9:1077:1081.

Singh, P., Khan, I.M., Singh, S., Tiwari, R.K., Shukla, U.N. and Philip, P. 2014. Performance of physiological basis of rice hybrids under system of rice cultivation. Bangladesh J. Bot., 43(3): 359-361.

Singh, R.K., Singh, A.N., Ram, H., Rajendra Prasad, S and Chauhan, R.K. 2013. Response of basmati (Oryza sativa L.) rice varieties to System of Rice Intensification (SRI) and conventional methods of rice cultivation. Ann. Agric. Res.,34(1): 50-56.

Sinha, S.K. and Talati, J. 2007. Productivity impacts of the system of rice intensification: A case study in West Bengal. India. Agric Water Manage., 87: 55-60.

SIWI, 2005. Stockholm International Water Institute (SIWI) policy institute for seeks sustainable solutions to the world's escalating water crisis. [www.siwi.org/ documents/Resources/Water accessed on 10/11/2013].

Soejima, H., Sugiyama, T., Ishihara, K. 1992. Changes in cytokinin activities and mass spectrometric analysis of cytokinins in root exudates of rice plant (Oriza sativa L.). Plant Physiol., 100, 1724-1729.

Soejima, H., Sugiyama, T., Ishihara, K. 1995. Changes in the chlorophyll contents of leaves and in levels of cytokinins in root exudates during ripening of rice cultivars Nipponbare and Akenohoshi. Plant Cell Physiol., 36:1105-1114. 
Sowmya, Ch. 2008. Studies on Integrated Nutrient management under System of Rice Intensification (SRI). M.Sc. (Ag.) Thesis. Acharya N G Ranga Agricultural University, Hyderabad, India.

Sridevi, V.and Chellamuthu, V. 2015. Growth analysis and yield of rice as affected by different system of rice intensification (SRI) practices. Int. J. Res. App. Nat. Social Sci., 3:29-36.

Stoop, A. W., Uphoff, N. and Kassam, A. 2002. A review of agricultural research issues raised by the System for rice intensification from Madagascar: Opportunities for improving farming systems for resource-poor farmers. Agric. Syst., 71:249-274.

Sujono, J. 2007. Water saving irrigation on paddy fields for increasing productivity and for flood reduction. Proceeding of the IASTED Internationa 1Conference on Water Resources Management(WRM).

Surendra, S., Sharma, S.N., Rajendra, P., Singh, S. and Prasad, R. 2001. The effect of seedling and tillage methods on productivity of rice -wheat cropping systems. Soil Tillage Res., 61:125-131.

Tao Longxing, Wang $\mathrm{Xi}$ and Min Shaokai (2002). Physiological effects of SRI methods on the rice plant. In : Assessments of the System of Rice Intensification (SRI):Proceedings of the International Conference. Sanya, China, April 1-4, 2002, ed.by N. Uphoff et at., pp. 132-136.

Terashima, I., Hikosaka, K. 1995. Comparative ecophysiology of leaf and shoot photosynthesis. Plant Cell Environ., 18:111-1128.

Thakur, A.K., Chaudhari, S.K., Singhandhupe, R.B. and Singh,R. 2006. Physiological basis of growth and development ofrice under SRI (System of Rice Intensification). In: Report from 2nd International rice congress, New Delhi, October 9-13.

Thakur, A.K., Rath, S., Patil, D.U., Kumar, A. 2011. Effects on rice plant morphology and physiology of water and associated management practices of the system of rice intensification and their implications for crop performance. Paddy Water Environ., 9:13-24.

Thakur, A.K., Rath, S., Roychowdhury, S., Uphoff, N. 2010. Comparative performance of rice with system of rice intensification (SRI) and conventional management using different plant spacings. J. Agron. Crop Sci., 196:14659.

Thakur, A.K., Sreelatha Rath., and Kumar, A. 2011. Performance evaluation of rice varieties under the System of Rice Intensification compared with the conventional transplanting system. Arch. Agron. Soil Sci., 57:223-238.

Udayakumar, 2005. Studies on System of Rice Intensification (SRI) for seed yield and seed quality. M. Sc. (Agri) Thesis, Acharya N.G. Ranga Agricultural University, Hyderabad.

Uphoff, N. 2001.Opportunities for Raising Yields by Changing Management Practices: The System of Rice Intensification in Madagascar. Agro ecological innovations: increasing food production with participatory development. Earthiscan Publications Ltd., London, Sterilin, VA, pp. 145-161.

Uphoff, N. 2002. Higher yields with fewer external inputs? The System of Rice Intensification and potential contribution to agricultural sustainability. Int. J. Agric. Sustain., 1(1): 38-50.

Uphoff, N. 2003. Higher yield with fewer external inputs in the system of rice intensification and potential contribution to agricultural sustainability. Inter. J. Agril. Sustain., 1 : 38-50.

Uphoff, N. 2004. The System of Rice Intensification: Capitalizing on existing yield potentials by changing management practices to increase rice productivity with reduced inputs and more profitability. In Proc. World Rice Research Conference, Tsukuba International Congress Centre, Japan, 5-7 November, 109. 
Uphoff, N. 2006. The system of rice intensification(SRI) as a methodology for reducing water requirements in irrigated rice production. Proceeding of the International Dialogue on Rice and Water: Exploring Options for Food Security and Sustainable Environment, pp: 7-8.

Uphoff, N. and Randriamiharisoa, R. 2002. Reducing water use in irrigated rice production with the Madagascar System of Rice Intensification (SRI). In: Water Wise Rice Production, IRRI,pp.71-87.

Uphoff, N., Kassam, A. and Harwood, R. 2011. SRI as a methodology for raising crop and water productivity: productive adaptations in rice agronomy and irrigation water management. Paddy Water Environ., (2011) 9:3-11.

USDA, 2016. United States Department of Agriculture;

http://www.fas.usda.gov/data/India-grainand-feed-animal.

Veerabhadram, G. 2013.Evaluation of rice (Oryza sativa L.) varieties and hybrids to system of rice intensification (SRI) method of cultivation and its effect on yield and quality parameters. M.Sc. (Ag.)
Thesis. Acharya N G Ranga Agricultural University, Hyderabad, India.

Verma, A. K., Pandey, N. and Shrivastava, G. K. 2014. Production potential and economics of hybrid rice under system of rice intensification and its manipulation. SAARC J. Agri., 12(2): 71-78.

Vishwakarma, A.,Singh, J.K., Singh, R.Kand Jat, A.L. 2016. Productivity and profitability of rice (Oryza sativa) hybrids as influenced by date of transplanting and age of seedling under system of rice intensification. Indian J. Agron., 61 (3): 315-320.

Yan Qingquan, 2002. The System of Rice Intensification and its use with hybrid rice varieties in China, In Assessments of the System of Rice Intensification (SRI): Proceedings of an International Conference held in Sanya, China, 1-4 April, 109-111.

Zhao, M., Wu, L.H., Li, Y.S., Animesh, S., Zhu, D.F. and Uphoff, N.2010. Comparisons of yield, water-use efficiency, and soil microbial biomass as affected by the system of rice intensification. Commun. Soil Sci. Plant Anal., 41:1-12.

\section{How to cite this article:}

Hari Kesh, Khushi Ram and Kuldeep Jangid. 2017. System of Rice Intensification: A Review on Resource Conserving Method of Rice Crop Establishment. Int.J.Curr.Microbiol.App.Sci. 6(11): 2315-2328. doi: https://doi.org/10.20546/ijcmas.2017.611.275 